\title{
Podizanje kvalitete matičnih nasada agruma u Republici Hrvatskoj
}

\author{
Establishment of Citrus mother blocks in Croatia
}

\author{
Mara Marić, Ivana Paladin
}

\section{SAŽETAK}

Zdravstveno stanje jedan je od ključnih čimbenika kakvoće sadnog materijala agruma. Terenskim i labaratorijskim istraživanjima utvrđena je zaraženost Citrus Tristeza virusom koji uzrokuje smanjenje bujnosti i rodnosti većine matičnih stabala agruma u nasadima Doline Neretve, najvažnijem području uzgoja te kulture u Hrvatskoj. Problem je prisutan već dugi niz godina jer se za nove nasade koriste pupovi iz proizvodnih nasada CAC kategorije (Conformitas Agraria Communitatis), dakle sa već zaraženih stabala. Matični nasadi viših kategorija zasnovani prema shemi EPPO, do sada nisu uspostavljeni. Podizanje takvih nasada, u predosnovnoj, osnovnoj i cerftificiranoj kategoriji, neophodno je za proizvodnju zdravog sadnog materijala, što je sadržano i u Direktivi Vijeća Europske unije (2008/90/EZ) o stavljanju na tržište reprodukcijskog sadnog materijala i sadnica namijenjenih proizvodnji voća. To je bila ujedno i polazišna točka pokretanja projekta „Podizanje kvalitete matičnih nasada agruma, jezgričavih i koštićavih voćnih vrsta u Republici Hrvatskoj“ Ministarstva poljoprivrede. Tako proizveden visoko kvalitetni sadni materijal omogućit će povećanje produktivnosti nasada agruma, te bolju pomološku vrijednost.

Ovim člankom, o postupku uspostavljanja certifikacijske sheme, su analizirani dostupni podaci o Italiji i Španjolskoj koje su vodeće europske zemalje u području agrumarstva. Konzultirana je i referentna znanstvena literatura.

Ključne riječi: agrumi, EPPO certifikacijska shema, matična stabla, sadni materijal

\section{ABSTRACT}

Health condition of the citrus planting material is one of the main factors of its quality. Field researchers and laboratory analyses in the the Neretva valley, the most important citrus cultivation area in Croatia, have identified that majority of mother trees is infected with the Citrus Tristeza virus, which causes a decrease in plant fertility. This problem has been present for many years now, mostly because buds are CAC category (Conformitas Agraria Communitatis), which means they originate from already infected trees. Mother blocks of higher categories, based on the EPPO scheme, have not been established yet. Raising this kind of mother blocks is necessary for the production of 
healthy reproductive planting material, and it is included in European Union Council directive $(2008 / 90 /$ EZ) on the marketing of fruit plant propagating material and fruit plants intended for fruit production. This was the starting point in initiating the Project „Establishment of mother blocks of citrus, pome fruits and stone fruits in the Republic of Croatia“ by the Ministry of Agriculture. Propagating the fruit material produced in this way will allow increase of the citrus plantations productivity and higher pomological value.

In this article, the procedure of the certification scheme is analyzed through examples of Spain and Italy, leading European citrus producers, along with the available scientific literature.

Keywords: citrus, EPPO certification scheme, mother blocks, planting material

\section{UVOD}

Naziv agrumi potječe od latinske riječi acrum, što znači oštro ili ljuto, a zajednički je naziv za voćne vrste iz botaničke podskupine Citrinae. U hrvatskom agrumarstvu najčešće su u nasadima vrste iz rodova Citrus, Fortunella i Poncirus, a ne samo rod Citrus, tako da bolje odgovara skupni naziv agrumi nego citrusi (Miljković, 1991).

U ovom radu analizira se komercijalni aspekt proizvodnje agruma, do kojeg je na Dubrovačkom području došlo nakon II. Svjetskog rata. Tada se u područje doline Neretve uvoze mandarine Unshiu, otporne na niske temperature. Danas agrumi za hrvatsko gospodarstvo predstavljaju jednu od najvažnijih poljoprivrednih kultura - u 2016. godini ostvaren je njihov izvoz u vrijednosti od 19 milijuna eura (Sočković, 2017.).

Međutim, zdravstveno stanje sadnog materijala agruma danas je nezadovoljavajuće i predstavlja veliki problem prilikom podizanja nasada. Terenska i laboratorijska istraživanja utvrdila su zaraženost većine stabala agruma $u$ dolini Neretve nekim od virusa, uključujući i matična stabla. Uglavnom se radi o virusu Citrus Tristeza koji uzrokuje smanjenje bujnosti i rodnosti nasada. Godine 2010. laboratorijskom analizom je utvrđena prisutnost CTV-a na 17 matičnih stabala od 147 testiranih stabala, pri čemu je odnos rasadnika bez CTV-a i s prisutnim CTV-om bio 33 : $66 \%$ (Ivić, 2012.).

Rješenje leži u proizvodnji zdravstveno ispravnog sadnog materijala, što je obveza Republike Hrvatske, a detaljno je propisano Pravilnikom o stavljanju na tržište reprodukcijskog sadnog materijala i sadnica namijenjenih za proizvodnju voća (NN 9/17) čime se prenose direktive Europske unije 2008/90/EZ, 2014/96/EU, i 2014/98/EU. 
Važeći propisi su podloga za proizvodnju zdravog sadnog materijala te time i razvoj rasadničarske proizvodnje. Tim propisima definirane su, u širem smislu, dvije različite kategorije sadnog materijala: CAC materijal (Conformitas Agraria Communitatis), najniža kategorija sadnog materijala, i materijal proizveden u sklopu certifikacijske sheme, odnosno materijal visokih kategorija. CAC kategorija je jedina koja se trenutno koristi u matičnjacima u Hrvatskoj za proizvodnju reprodukcijskog sadnog materijala agruma, a osim sortne čistoće, odsutnost parazita i štetnika utvrđuje se vizualnim pregledom. S druge strane, materijal proizveden u sklopu certifikacijske sheme podvrgava se rigoroznim testiranjima, po potrebi ozdravljuje, a čuva se i razmnožava u posebno zaštićenim prostorima (Ivić i Fazinić, 2011.). Takav sadni materijal u Hrvatskoj je u postupku uspostavljanja.

Certifikacijska shema prema Europskoj i mediteranskoj organizaciji za zaštitu bilja (u daljnjem tekstu: EPPO) je sustav proizvodnje vegetativnog razmnožavanja bilja namijenjenog za sadnju, daljnje razmnožavanje ili prodaju, dobivenog iz predosnovnog matičnog materijala nakon nekoliko faza razmnožavanja u uvjetima koji zadovoljavaju navedene zdravstvene standarde (EPPO, 1998). Takav zdravi sadni materijal čuva se u tzv. objektu mrežarnika pod uvjetima sigurne zaštite, gdje se provodi sanitarni nadzor i time se smanjuje mogućnost ponovne zaraze.

Sa svrhom uspostavljanja uvjeta za proizvodnju zdravog sadnog materijala u Hrvatskoj, Ministarstvo poljoprivrede Republike Hrvatske pokrenulo je projekt uspostave matičnih nasada agruma viših kategorija kojeg provodi Zavod za mediteranske kulture, Sveučilišta u Dubrovniku. Navedeno će omogućiti podizanje novih matičnjaka u rasadnicima.

Cilj ovog rada je predstaviti stanje proizvodnje sadnica agruma $u$ Dubrovačko-neretvanskoj županiji, prezentirati iskustva europskih zemalja Španjolske i Italije u postupku uspostavljanja certifikacijske sheme te na temelju dostupne referentne literature, izvesti zaključke o uspostavi tog postupka u Republici Hrvatskoj.

\section{UZGOJ AGRUMA NA PODRUČJU DUBROVAČKO-NERETVANSKE ŽUPANIJE}

\section{Povijest uzgoja agruma na Dubrovačko-neretvanskom području}

Različite vrste agruma, pogotovo četruni i ljute naranče uzgajaju se u vrtovima dubrovačkog kraja još od srednjeg vijeka, a posebno u renesansi, o čemu svjedoče pisana djela brojnih putopisaca koji su posjećivali Dubrovnik.

Komercijalni uzgoj agruma kreće u prvim desetljećima 20. stoljeća. 
U djelu „Neke južne kulture“ iz 1923. Mato Bobanović navodi kako je tada u Dalmaciji bilo 10.800 stabala agruma. Tu se i prvi put spominje mandarina Unshiu, koja i danas zauzima najveće površine u dolini Neretve i predstavlja glavnu komercijalnu kulturu agruma Republike Hrvatske (Kaleb, 2014.).

Prve mandarine u dolini Neretve posađene su 1940. godine sadnicama koje su donešene iz rasadnika u Tivtu. Te sadnice bile su dijelom pošiljke od 372 sadnice agruma iz Japana koje su brodom prvo stigle u Bar, a kasnije su se dijelile duž crnogorskog primorja i Dalmacije (Kaleb, 2014). O potrebi i problematici proširenja agruma u Hrvatskoj izvještava nas Tabain (1949). Prvi prijedlog regionalizacije uzgoja agruma u Hrvatskoj izradili su Tabain, F. i Miljković I., (1978). U prijedlogu su naznačena područja prikladna za uzgoj pojedinih vrsta i sorti agruma.

Nakon II. svjetskog rata, dolazi do snažnijeg komercijalnog razvoja agrumarstva. Prvi nasad mandarine Unshiu sorte Owari podignut je 1951. godine, površine 0,22 ha, na lokalitetu „Pošte“ kraj Opuzena. To je jedan od najstarijih nasada mandarine koji je dugi niz godina davao visoke prinose (Baraba i sur., 1987.).

Ključna godina za intenziviranje agrumarstva u dolini Neretve je bila 1959., kada se osniva Poljoprivredno-industrijski kombinat „Neretva“ u Opuzenu (u daljnjem tekstu: PIK „Neretva“).

PIK „Neretva“ je bio najveći voćni i lozni rasadnik u tadašnjoj državi i među najvećim izvoznicima biljnog materijala (Kaleb, 2014.).

U razdoblju od 1960 do 1967 nastaje prva komercijalna plantaža mandarine Unshiu, sorte Owari na lokalitetu „Luke“ ukupne površine od 52 ha u vlasništu PIK-a koji je predstavljao najveći nasad agruma u bivšoj Jugoslaviji (Bakarić, 1983.).

Proizvodnja agruma, posebno mandarina Unshiu pokazala je visoki potencijal. Značajna je 1962. godina kada je sklopljen ugovor između međunarodne organizacije FAO u Rimu i jugoslavenske vlade u Beogradu o projektiranju melioracija i osvajanja močvarnog dijela delta Neretve pod imenom Opuzen - Ušće. Stručnjak A.D. Aleksandrov iz SSSR-a boravi u Opuzenu te prvi ukazuje na potrebu intodukcije ranijih sorti Kavano Wase, Myagava Wase i drugih agruma (Kaleb, 2014) koje su i uslijedile 1966.godine (Gatin, 1978).

Međunarodna organizacija FAO upućuje u PIK „Neretva“ svoje stručnjake koji otvaraju perspektive razvoja agruma. Dijele korisne savjete o virusnim bolestima citrusa i upotrebi bezvirusnih klonova te 1973. godine nabavljaju nove sorte i vrste za ispitivanje u nasadima u donjoj Neretvi. Među njima su se našli Klementina, Fairchild, Carvalhal, Saigon, Owari, brojni limuni, naranče, dekorativni agrumi i nekoliko vrsta podloga (Gatin, 1978.). 
Tijekom ratnih devedesetih godina dolazi do raspada PIK-a „Neretva“, zapuštanja i neodržavanja kolekcijskih, matičnih i pokusnih nasada agruma u dolini Neretve gdje se nalaze najveće površine agruma pod mandarinkom Unshiu (Gugić i Cukrov, 1998.).

Osim doline rijeke Neretve, ekstenzivni nasadi agruma nalaze se na cijelom dubrovačkom obalnom području, od Konavala, preko Rijeke Dubrovačke, sve do otoka Koločepa, Lopuda, Šipana i Mljeta (Čmelik i sur., 2010.).

\section{Uloga rasadnika Čibača u uzgoju agruma}

Zavod za mediteranske kulture ili nekadašnja Stanica za južne kulture osnovana je 1945. godine $\mathrm{s}$ ciljem unapređenja poljoprivrede u južnoj Dalmaciji. Stanici je 1963. godine pripojen rasadnik Čibača koji je ujedno i najstarija jedinica Zavoda za mediteranske kulture (Marić, 2015). Prema arhivskim dokumentima osnovan je 1911. godine s ciljem sprečavanja propasti vinograda i uzgojem američkih loznih podloga (Penava, 2017).

U narednim godinama, Rasadnik Čibača na jugu Hrvatske stvara temelje razvoja mediteranske poljoprivrede $i$ to uzgojem i širenjem kultura karakterističnih za ovo područje. Organiziraju se brojni stručni tečajevi te se proizvode sadnice voćaka.

Zajedno sa Stanicom za južne kulture, 1948. godine, u rasadniku Čibača dolazi do početka uzgoja agruma i proizvodnje prvih sadnica i podloga mandarine Unshiu, a to je ujedno bio i sam početak organizirane proizvodnje i uzgoja mandarina u Dalmaciji (Bakarić, 1983).

Prve plantaže mandarine Unshiu, na objektu Luke, PIK „Neretva“ u Opuzenu podignute su sadnicama iz dubrovačkog rasadnika (Gatin, 1978).

Iz dubrovačkih ustanova, Stanice za južne kulture i rasadnika Čibača, isporučeno je nekoliko desetaka tisuća sadnica mandarine Unshiu po cijeloj Hrvatskoj i bivšoj Jugoslaviji (Bakarić, 1983.).

Osim u praktičnom smislu, nekadašnja Stanica za južne kulture imala je veliku ulogu u edukaciji o biološkoj i gospodarskoj vrijednosti agruma, a posebice mandarine Unshiu (Bakarić, 1983.; 1994.; 1974.; 1998.), (Tabain, 1975.).

\section{Današnja situacija uzgoja agruma u Hrvatskoj}

Od ukupne površine registriranih voćnjaka u Hrvatskoj, nasadi agruma zauzimaju 6,2 \% (Državni zavod za statistiku RH, 2012.). Prema baznom istraživanju 2015. godine agrumi su u Hrvatskoj zauzimali oko 2.500 hektara obradive površine, od čega najviše u Dubrovačko-neretvanskoj županiji (Državni zavod za statistiku RH, 2015.). 
Dolina Neretve, kao geografski krajnje uzgojno područje na kojem mogu uspijevati agrumi, najveće je i gospodarski najvažnije agrumarsko područje u Hrvatskoj. Najveći dio obradive površine zauzima mandarina sortne skupine Unshiu. Na tom području, za ostale agrume su manje povoljni uvjeti uzgoja zbog niskih temperatura.

Raspadom „PIK Neretva“ 3000 ha obradive zemlje je postalo državno vlasništvo, koje je kasnije podjeljeno privatnicima (Soldo, 2004.). Danas oko 700 proizvođača obrađuje površine nekadašnjeg poljoprivrednog kombinata „PIK Neretva“ (Ljubičić, 2015). Statistički zapisi o površinama nasada na razini županije ne postoje od 2007. godine.

Tablica 1. Površine, prirodi i proizvodnja agruma 2011. - 2015. (izvor: Državni zavod za statistiku, 2012. -2016.)

Table 1 Areas, yields and citrus production, 2011-2015 (source: Agricultural Census, Croatian Bureau of Statistics, 2012-2016)

\begin{tabular}{|c|c|c|c|c|c|c|c|}
\hline & & & 2011. & 2012. & 2013. & 2014. & 2015. \\
\hline \multirow{5}{*}{ MANDARINE } & & Površina,ha & 1.760 & 1.720 & 2.104 & 2.150 & 2.150 \\
\hline & \multirow{2}{*}{$\begin{array}{l}\text { Intezivni } \\
\text { nasad }\end{array}$} & $\begin{array}{c}\text { Proizvodnja, } \\
\mathrm{t}\end{array}$ & 41.870 & 80.786 & 40.024 & 64.378 & 35.722 \\
\hline & & $\begin{array}{c}\text { Prirod po ha, } \\
\mathrm{t}\end{array}$ & 24 & 30 & 19 & 29,9 & 16,6 \\
\hline & $\begin{array}{c}\text { Proizvodnja } \\
\text { ekstenzivnih nasada, } \mathrm{t}\end{array}$ & & 505 & 294 & 293 & 622 & 214 \\
\hline & Ukupno proizvodnja, $\mathrm{t}$ & & 42.375 & 51.080 & 40.317 & 65.000 & 35.936 \\
\hline \multirow{5}{*}{ NARANČE } & & Površina,ha & 50 & 43 & 59 & 31 & 32 \\
\hline & \multirow{2}{*}{$\begin{array}{l}\text { Intezivni } \\
\text { nasad }\end{array}$} & $\begin{array}{c}\text { Proizvodnja, } \\
\mathrm{t}\end{array}$ & 315 & 269 & 145 & 106 & 158 \\
\hline & & $\underset{t}{\text { Prirod po ha, }}$ & 6 & 6 & 3 & 3 & 5 \\
\hline & $\begin{array}{c}\text { Proizvodnja } \\
\text { ekstenzivnih nasada, } \mathrm{t}\end{array}$ & & 18 & 15 & 10 & 10 & 97 \\
\hline & Ukupno proizvodnja, $\mathrm{t}$ & & 333 & 284 & 155 & 116 & 255 \\
\hline \multirow{5}{*}{ LIMUNI } & & Površina, ha & 40 & 29 & 11 & 20 & 30 \\
\hline & \multirow{2}{*}{$\begin{array}{l}\text { Intezivni } \\
\text { nasad }\end{array}$} & $\begin{array}{c}\text { Proizvodnja, } \\
\mathrm{t}\end{array}$ & 200 & 195 & 240 & 181 & 183 \\
\hline & & $\begin{array}{c}\text { Prirod po ha, } \\
\mathrm{t}\end{array}$ & 5 & 6,7 & 22 & 9,1 & 6,1 \\
\hline & $\begin{array}{c}\text { Proizvodnja } \\
\text { ekstenzivnih nasada, } \mathrm{t}\end{array}$ & & 8 & 5 & 5 & 15 & 71 \\
\hline & Ukupno proizvodnja, $\mathrm{t}$ & & 208 & 200 & 245 & 196 & 254 \\
\hline
\end{tabular}


U tablici 1. prikazane su ukupne površine pod intezivnom proizvodnjom agruma za cijelu Hrvatsku,a prepostavlja se da je većina komercijalnih nasada smještena u Dubrovačko-neretvanskoj županiji (Dolina Neretve). Ukupna proizvodnja mandarine, naranči i limuna u RH u 2016. godini iznosila je oko 53 500 tona, a glavnina ukupne proizvodnje odnosi se na mandarinu. U 2015. godini urod mandarina bio je dvostruko manji u odnosu na 2014. godinu. Razlog tome bila je pojava orkanske bure koja je otpuhala sve cvjetove, ali i pojava kasnih proljetnih mrazeva (Musulin, 2015). U odnosu na 2015.godinu proizvodnja agruma u 2016.g povećala se za oko 20000 tona (Državni zavod za statistiku RH, 2016).

Prema baznom istraživanju o sortnoj strukturi u nasadima mandarine (Graf 1) najzastupljenije sorte su Kavano Wase, Chachara, Zorica rana i Unshiu Owari (Državni zavod za statistiku RH, 2013.).

Graf 1. Najzastupljenije sorte mandarine u intenzivnom uzgoju (izvor: Državni zavod za statistiku, 2012.)

Chart 1 The most common mandarin varieties in intensive cultivation (source: Agricultural Census, Croatian Bureau of Statistics, 2012)

Najzastupljenije sorte mandarine

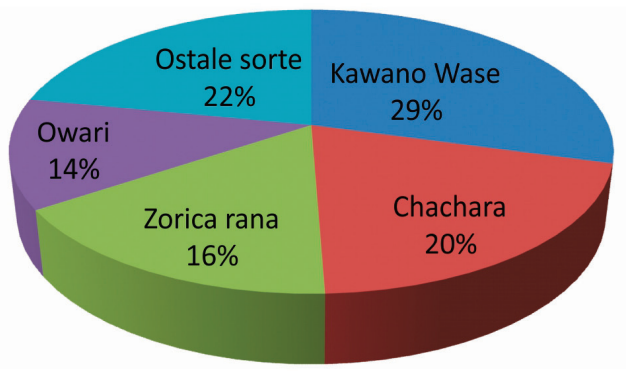

U popisu sorti voćnih vrsta u 2016. godini upisano je 12 sorti mandarine, 7 sorti limuna, 4 sorte grejpfruta, 4 sorte naranče i 1 sorta šedoka (HCPHS, 2016.).

Plodovi mandarine uzgojeni u dolini Neretve su izrazito velike biološke vrijednosti, specifičnog slatko-kiselkastog okusa i arome. Karakteristični makroklimatski i mikroklimatski uvjeti u dolini Neretve, kao što su temperaturi, kemijski sastav tla, utječu na razvijanje plodova mandarine specifičnih senzorskih svojstava. Godine 2015. „Neretvanska Mandarina“ je upisana u 
registar zaštićnih oznaka izvornosti i zemljopisnog podrijetla, kako bi se zbog tih specifičnih karakteristika plodova mandarine uzgojenih u dolini Neretve istaknula kvaliteta i zemljopisno podrijetlo te kako bi se proizvod etabliarao na inozemnom tržištu. Proizvodi koji nose oznaku izvornosti postižu višu cijenu i imaju bolji plasman na tržištu (Crnomarković i Kiridžija, 2013.).

U novije vrijeme, u dolini Neretve sve se više ljudi okreće uzgoju maslina i jednogodišnjih kultura povrća (Kaleb, 2014.). Razlozi su niska cijene otkupa agruma, smanjena konkurentost na tržištu zbog sezonalnosti proizvodnje u odnosu na druge mediteranske zemlje, slabo održavanje agromelioracijskog sustava, usitnjenost parcela i sve veća populacija sredozemne voćne muhe.

Jedan od većih problema uzgoja agruma je i zaraženost matičnih stabala Citrus Tristeza virusom (Ivić, 2012.). Ova bolest izaziva gubljenje vitalnosti, kvržljavost, sušenje grana agruma te istodobno dolazi do nekroze floema i propadanja korijena što rezultira uginućem stabala (Festić, 1979.).

Ujedno ova bolest predstavlja veliki problem zbog zaraženosti postojećeg sadnog materijala i nezadovoljavajućih fitosanitarnih zahtjeva, pa nije moguće izdati biljnu putovnicu te takav materijal staviti na tržište EU.

S obzirom na prostorno-klimatske predispozicije, gospodarski potencijal i dugogodišnju tradiciju uzgoja agruma u Dubrovačko - neretvanskoj županiji, potrebno je postojeći sustav proizvodnje sadnog materijala agruma osuvremeniti uspostavom certifikacijske sheme. Jedan od koraka za uspostavu certifikacijske sheme je osuvremenjavanje kompletne proizvodnje agruma, odnosno uspostava novih matičnih nasada više kategorije.

\section{ISKUSTVA ŠPANJOLSKE I ITALIJE U PODIZANJU MATIČNIH NASADA AGRUMA VIŠE KATEGORIJE}

Zbog pada produktivnosti i ograničenosti proizvodnje agruma uzrokovanih virusom i virusima slične bolesti, većina agrumarskih zemalja provodi certifikacijski program radi obnove ili očuvanja sadnog materijala (Vapnek, 2009.).

Prema literaturi program certifikacije u svijetu kreće već u 1930-tim godinama, kad je u Eksperimentalnoj stanici za agrume u Riversideu, u Kaliforniji, otkrivena prva cijepljenjem prenosiva bolest, Citrus psorosis (Vapnek, 2009.). To je dovelo do uspostave prvog rasadnika sa zdravim plemkama. Tijekom godina, sustav očuvanja zdravog sadnog materijala je znatno napredovao, a danas je poznat pod nazivom „Program zaštite klonova citrusa" (Citrus Clonal Protection Program - CCPP) koji održava bezvirusne 
nasade agruma, sortno čiste plemke za sve vrste citrusa i podloga iz svih dijelova Kaliforije i svijeta (Vapnek, 2009.).

U sklopu pripreme projekta podizanja matičnih nasada agruma u Hrvatskoj, Zavod za mediteranske kulture Sveučilišta u Dubrovniku upoznao se $\mathrm{s}$ iskustvima vodećih europskih zemalja u području agrumarstva - Italije i Španjolske, kroz uvid u rad Tehničkog zavoda za poljoprivredu "Basile Caramia" u Locorotondi (Istituto Tecnico Agrario "Basile Caramia" di Locorotondo), te Poljoprivrednog istraživačkog centra u Valenciji (Instituto Valenciano de Ivestigaciones Agrarias - IVIA).

\section{Španjolska}

Problemi u proizvodnji agruma u Španjolskoj počeli su pojavom virusa Citrus Tristeza 1957. godine (Navarro i sur., 2002). Godine 1972. virusom je bilo zahvaćeno 82000 ha, zbog toga što se kao podloga uglavnom koristila izrazito osjetljiva gorka naranča (Citrus aurantium), čija se upotreba nakon toga sve više smanjivala (Navarro, 1975.). Procijenjeni gubici kretali su se od 10 do $25 \%$ ukupne proizvodnje (Navarro i sur., 2002.). Ubrzo nakon toga poduzete su mjere za rješavanje ovog problema. Pokrenut je program poboljšanja uzgoja agruma - CVIPS (The Citrus Variety Improvement Program in Spain) 1975. godine, koji je reguliran certifikacijskom shemom.

Program se temeljio na pet osnovnih faza koje su podjednako važne za dobivanje zdravstveno ispravnog materijala:

1. Program ozdravljivanja - dobivanje bezvirusnih biljaka mikrocjepljenjem in vitro,

2. Predosnovni nasad - održavanje zdravih genotipova kao banke gena,

3. Certifikacijski program - sortna i zdravstvena kontrola komercijalne proizvodnje,

4. Karantenski program - introdukcija novih sorata,

5. Opskrba rasadničara zdravim sadnim materijalom proveden kroz certifikacijsku shemu (Navarro i sur., 2002).

Odgovornost za provođenje ovog programa u Španjolskoj u znanstvenom i tehnološkom aspektu za prvu i drugu fazu u postupku certifikacije preuzeo je poljoprivredni istaživački centar - IVIA (Instituto Valenciano de Investigaciones Agrarias) (Anonymous, 2016).

Najvažniji i najkompleksniji postupak certifikacijske sheme je postupak ozdravljenja. S obzirom da u Republici Hrvatskoj zasad nije bilo iskustva $\mathrm{s}$ ozdravljivanjem agruma, u nastavku rada opisano je kako se taj postupak provodi u Španjolskoj. 
Početni postupak u provođenju programa je selekcija matične biljke bazirana na hortikulturalnim (vigor stabla, list, visina stabla itd.) i pomološkim vrijednostima, bez simptoma bolesti. Nakon toga slijedi indeksiranje matične biljke okulacijom pupa na biljku indikator. Tako okulirane biljke čuvaju se u mrežarniku na temperaturma od 18 do $32^{\circ} \mathrm{C}$, ovisno o indikatorskoj biljci za pojedinu bolest (Navarro i sur., 1981.). Uviđanjem zaraženosti na indikatorskoj biljci slijedi ozdravljivanje biljnog materijala što je osnova očuvanja genotipa. Postupak eliminacije patogena iz zaražene biljke traje 2 mjeseca i postindeksiranje šest do sedam mjeseci (Aubert i Vullin, 1998.). Tehnika koja se koristi u ozdravljenju je shoot-tip micrografting , in vitro“ jedna od najboljih metoda za eliminaciju patogena kod agruma. Naime, to je mikrocjepljenje apikalnog vrška pupa na dekapitirani sjemenjak podloge u uvjetima in vitro (Roistacher i sur., 1976.). Većina virusa kod agruma se ne prenosi sjemenom te se kao takvi steriliziraju i uzgajaju na hranjivoj podlozi u epruveti, a vegetacijski vršci biljaka zaraženih virusom najčešće su bez virusih čestica. Ovaj postupak cijepljenja u uvjetima in vitro pokazao se kao najbolja metoda dobivanja bezvirusnih biljaka koje su istodobno identične majčinskoj biljci (Rošin, 2009 prema: Kassanis, 1957.). Sve sadnice koje uđu u Španjolsku prolaze kroz karantenski program koji se sastoji od steriliziranja mladice, indeksiranja i ozdravljivanja. Biljni materijal koji je prošao proces mikrocjepljenja čuva se u zaštićenom mrežarniku na temperaturi od 18 do $25{ }^{\circ} \mathrm{C}$. Nakon 7 do 8 mjeseci razvoja biljke, obavlja se indeksiranje pomoću biljaka indikatora i pomoću laboratorijskih metoda (ELISA test, PCR, RTPCR). Utvrđivanjem nepostojanja patogena, biljni materijal prelazi u predosnovni nasad (Navarro, 1981.). Smješten je u objektu mrežarnika izgrađenog prema EPPO certifikacijskoj shemi. To je objekt s dvostrukom mrežom, zaštitnim predulazom i služi za čuvanje bezvirusnog biljnog materijala. U njemu se provodi strogi stručni nadzor i upotrebljavaju sredstva za zaštitu bilja, čime se smanjuje mogućnost ponovne zaraze.

U institutu IVIA se čuva predosnovni nasad kojeg čine 503 genotipa, a 362 pripadaju rodu Citrus, hibridi čine 102 i 39 genotipova srodnih rodova (Montalt, 2009.).

Predosnovni nasad je jedinstveni izvor biljnog materijala za dobivanje zdravog sadnog materijala, kategorije osnovni u mrežarnicima, stvaranjem gustog sklopa na otvorenom kategorije osnovni. Sva ta stabla koja čine osnov za komercijalno razmnožavanje uključena su u certifikacijski program. Gusti sklop na otvorenom omogućava dobivanje većeg broja plemki i time opskrbu rasadničara za podizanje vlastitih osnovnih nasada. Trenutno, postoji 39 


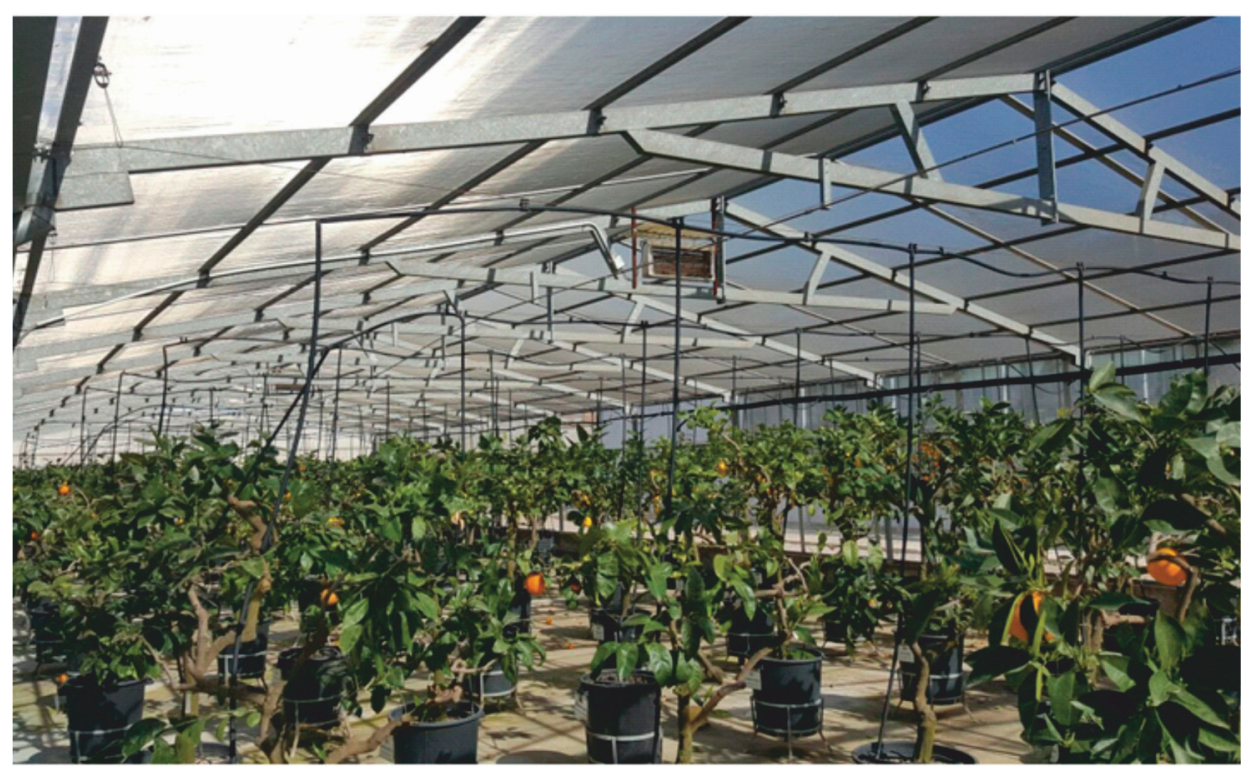

Slika 1. Predosnovni matični nasad agruma, IVIA, Španjolska (izvor: foto. Ivana Paladin)

Picture 1 Pre-basic mother block of Citrus, IVIA, Spain (source: Ivana Paladin)

registriranih rasadnika, koji koriste plemke iz predosnovnog nasada za svoje komercijalno razmnožavanje (Navarro i sur., 2002.).

Danas je Španjolska glavni proizvođač agruma u Europi, sa 294720 ha i ukupnom proizvodnjom od 7 milijuna tona (Valverde, 2016.). Program unaprijeđenja uzgoja agruma bio je od ključne važnosti za Španjolsku u postizanju vodeće pozicije. Prema podacima phD. M.C. Vives, voditeljice odjela za biotehnologiju u institutu IVIA, u Španjolskoj je posađeno 150 milijuna bezvirusnih stabala dobivenih kroz certifikacijsku shemu, što čini 99\% proizvodnje agruma (M. C. Vives, 2016.).

\section{Italija}

Destruktivne bolesti poput Citrus Tristeza Virus i ostale bolesti prenosive krilatim vektorima, nađene su na samo nekoliko izoliranih točaka u Italiji (Savino, D’Onghia, 1998), i nisu predstavljale veći problem sve do 2002. godine, kada je izbila epidemija, pogotovo na Siciliji i u Apuliji (Djelouah 2009). Međutim, zdravstveno stanje agrumika je bilo ozbiljno ugroženo zbog širenja bolesti koje su prenosive putem reprodukcijskog materijala. Urod i životni vijek stabala bili su u opadanju, a razvoj uzgoja agruma ugrožen. 
S obzirom na neučinkovitost kemijskih sredstava protiv takvih vrsta bolesti, jedini način kontrole bila je prevencija. To je uključivalo nužnost primjene certifikacije, odnosno skupa tehničkih i zakonskih procedura koje će osigurati kvalitetu gotovog reprodukcijskog materijala koji potječe od matične biljke, provjerene sortne čistoće i testirane na virusne bolesti (Savino, D'Onghia, 1998.). Godine 1991. počeo se provoditi dobrovoljni certifikacijski program, a 1993. godine izdana je „Tehnička odredba za proizvodnju certificiranog reprodukcijskog materijala agruma“ (Savino, D’Onghia, 1998.).

Zbog pojave novih štetnika, bolesti i novih dijagnostičkih tehnika dolazi do mijenjanja regulativa. Godine 2003. izdana je nova odredba o organiziranju Nacionalne službe za provođenje certifikacije reprodukcijskog sadnog materijala. Uspostavilo ju je Ministarstvo poljoprivrede Republike Italije i sastoji se od tehničkog odbora, operativnog dijela i regionalne fitosanitarne službe. Potonje su odgovorne za certifikaciju (kontrolu zdravstvene ispravnosti i sortne čistoće) na svom teritoriju. Na kraju 2006. godine izdan je prijedlog o tehničkim protokolima za proizvodnju certificiranog sadnog materijala agruma (Catalano, 2008.).

Slijedom navedenoga, danas se certifikacijski program u Italiji sastoji od:

\section{Centra za čuvanje predosnovnog biljnog materijala (Predosnovni biljni materijal).}

Selektirana biljka nakon procesa ozdravljenja i registracije prebacuje se u Centar i time postaje predosnovni biljni materijal. Centar služi za održavanje predosnovnog matičnog nasada a čine ga dvije biljke od izabrane matične biljke (Savino D’Onghia, 1998.). Čuvaju se unutar mrežarnika koji mora udovoljavati propisanim fitosanitarnim odredbama.

\section{Centra za predumnažanje (Osnovni biljni materijal).}

Ovdje se provodi cijepljenje i stvaranje sadnog materijala osnovne kategorije iz predosnovnog biljnog materijala (Savino D’Onghia,, 1998). Čuva se u zaštićenim mrežarnicma u loncima odgovarajuće veličine, sterilnog supstrata i odvojenih od tla. Fitosanitarne odredbe su propisane dekretom Ministarstva poljoprivrede.

\section{Reprodukcijskog centra (Certificirani biljni materijal).}

Služi za dobivanje certificiranog sadnog materijala (sadnice i sjemena) za rasadnike. Certificirana matična biljka raste na parcelama bez patogena, najmanje 100 metara udaljena od susjednog voćnjaka. Tijekom redovite kontrole, mora biti bez patogena. Prema talijanskom standardu, eksplatacija nasada za proizvodnju pupova može trajati 30 godina, a sjemena 40 godina (Savino, D’Onghia, 1998.). 


\section{Gustog sklopa i rasadnika}

Gusti sklop čini osnovni sadni materijal posađen najmanje 50 metara od komercijalnog nasada agruma i služi za dobivanje većeg broja plemki. Rasadnik mora biti odobren od fitosanitarne službe i imenovan za proizvodnju certificiranog reprodukcijskog sadnog materijala (Savino, D’Onghia, 1998.). Kontrolu sadnog materijala obavlja fitosanitarna služba koja provodi kontrolu nad sortnom čistoćom i zdravstvenim stanjem biljke (Ministral Decree, 2006.).

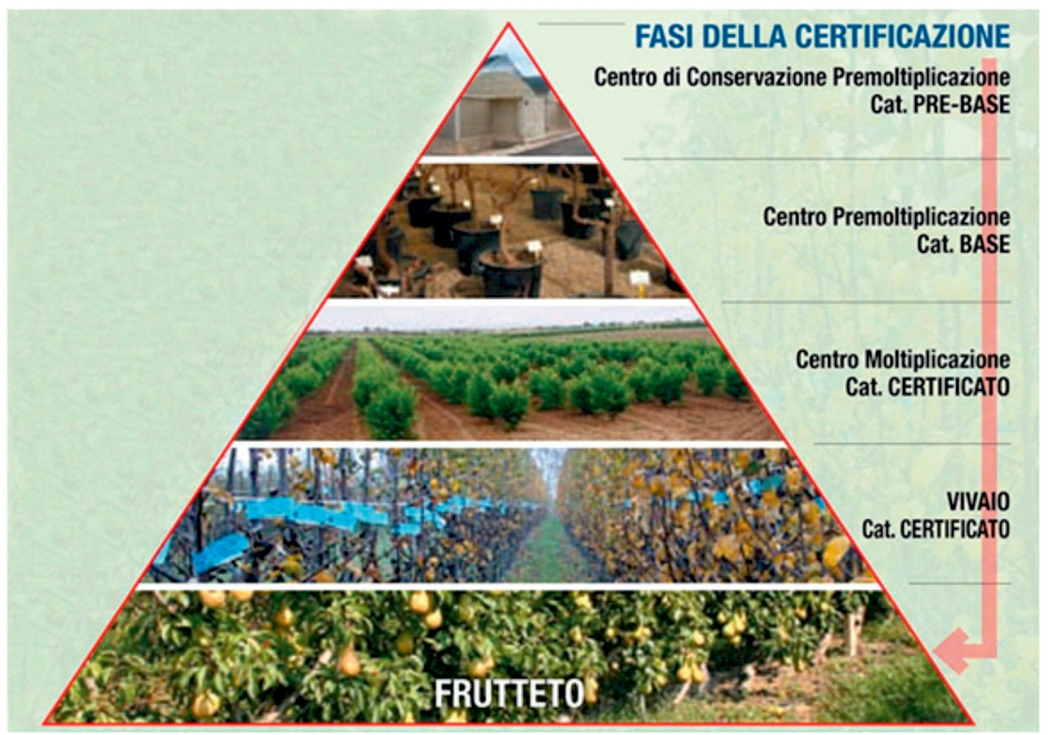

Slika 2. Certifikacijski program Italije - shema (izvor:www.vivaitopplant.it)

Picture 2. Italy Certification program-scheme (source:www.vivaitopplant.it)

U Italiji postoji osam centara za čuvanje predosnovnog matičnog nasada i devet centara za predumnažanje. Od toga samo dva centra provode certifikacijski program za agrume, uz ostalo voće, a to su CRSA "B. Caramia" Locorotondo-Regija Puglia i C.R.A. ISA Acireale-regija Sicilija (Catalano, 2008.).

Odgovornost za koordinaciju certifikacijskog sustava na državnoj razini povjerena je Ministarstvu poljoprivrede, hrane i šumarstva, kroz Nacionalnu certifikacijsku službu i poseban Nacionalni odbor za certifikaciju. U centrima za preumnažanje i umnažanje unutar regija, certifikacijski program provodi se na više voćnih vrsta zajedno.

Italija je danas druga u Europi po proizvodnji agruma, s oko 2 milijuna tona i površinama približno 150000 hektara (Bettini, 2016.). 
PREDUVJETI FORMIRANJA MATIČNIH NASADA VISOKIH KATEGORIJA (PREDOSNOVNI I OSNOVNI) NA POLIGONU ČIBAČA, ZAVODA ZA MEDITERANSKE KULTURE, SVEUČILIŠTA U DUBROVNIKU

U dosadašnjem razdoblju u Hrvatskoj su se koristila isključivo matična stabla iz proizvodnih nasada CAC kategorije. Matični nasadi viših kategorija sadnog materijala dosad još nisu uspostavljeni (Ivić, 2012.). Prema Direktivi Vijeća EU 2008/90/EZ o stavljanju na tržište reprodukcijskog sadnog materijala i sadnica namijenjenih proizvodnji voća, neophodna je proizvodnja zdravog sadnog materijala predosnovne, osnovne i certificirane kategorije (Ministarstvo poljoprivrede, 2016.).

Prema planu projekta „Podizanje kvalitete matičnih nasada agruma“ Ministarstva poljoprivrede što ga provodi Zavod za mediteranske kulture Sveučilišta u Dubrovniku, obavio bi se postupak selekcije i analiza sortnih svojstava biljaka iz postojećih matičnih nasada (Ministarstvo poljoprivrede, 2016.).

Predosnovni i osnovni bezvirusni matični nasad činilo bi 16 sorata agruma i 3 vrste podloga sa sortne liste Republike Hrvatske. U skladu s certifikacijskom shemom planiran je program ozdravljivanja i podizanje osnovnih nasada ozdravljenih genotipova. U tu svrhu planirana je izgradnja objekta mrežarnika.

Mrežarnik bi se gradio prema EPPO certifikacijskoj shemi u kojem bi se čuvao ozdravljeni sadni materijal. Predosnovni biljni materijal bi se održavao u mrežarniku uz provođenje strogog sanitarnog nadzora. Sadio bi se u lonce dovoljne veličine sa sterilnim supstratom. Lonci bi morali biti odvojeni od tla $u$ mrežarniku i u uvjetima u kojima nije moguća zaraza preko korijena, polenom, vektorima iz zraka ili tla (Narodne Novine 9/17). Planirano je čuvati četiri biljke po jednoj sorti, koje će se testirati na viruse i viroide svakih šest godina (Ministarstvo poljoprivrede, 2016.).

Planirana je također uspostava i osnovnog matičnog nasada u mrežarniku.

Mrežarnik bi se podigao na lokaciji rasadnika Čibača, $10 \mathrm{~km}$ istočno od grada Dubrovnika u Dubrovačko-neretvanskoj županiji. Područje ima obilježje tipične sredozemne klime koju karakteriziraju topla i suha ljeta s temperaturnim maksimumom i do $38^{\circ} \mathrm{C}$. Zime su umjereno blage s negativnim maksimumum do $-8^{\circ} \mathrm{C}$. Udari bure i olujnih vjetrova su izraziti u kasnu jesen i zimu (DHMZ, 2016).

U sklopu izgradnje mrežarnika predviđeno je čišćenje terena za izgradnju objekta, koji prema EPPO certifikacijskoj shemi mora biti primjereno konstruiran, nepropusan za insekte, prijenosnike virusa i virusu sličnih 
organizama čime se osigurava zaštita od ponovne zaraze. Mrežarnik mora biti opremljen predprostorom $s$ dvostrukim ulazom te zaštićen od površinskih i oborinskih voda. Okolna zona mrežarnika mora biti bez vegetacije u krugu od najmanje 2 metra (EPPO, 1998.).

$\mathrm{Na}$ otvorenom polju podigao bi se nasad sadnica osnovne kategorije s kojeg bi se uzimale plemke za opskrbljivanje rasadničara. Na tako uzgojenim biljkama provodio bi se postupak certifikacije (Ministarstvo poljoprivrede, 2016.).

Prema EPPO certifikacijskoj shemi matični nasad na otvorenom mora biti odvojen barem $100 \mathrm{~m}$ od necertificiranog materijala agruma i umjereno izoliran od izvora zaraze. Takav matični materijal treba držati pod nadzorom i obavljati redovitu zaštitu odgovarajućim sredstvima za zaštitu bilja (EPPO, 1998.)

\section{ZAKLJUČAK}

Zdravi sadni materijal je uvjet podizanja kvalitete proizvodnih nasada na višu razinu. Proizvodnja sadnog materijala kroz certifikacijsku shemu rezultirala bi kakvoćom prinosa, rodnošću biljke i općenito rentabilnošću cijelog nasada. Proizvodnja zdravih sadnica smanjiti će širenje gospodarski važnih parazita agruma, a time će omogućiti razinu kakvoće sadnog materijala sukladno europskom standardu. Formiranjem predosnovnog i matičnog nasada čuva se genetska čistoća najvažnijih sorti agruma, i nastaje ishodišna točka za formiranje osnovnog matičnog nasada, s kojeg bi se uzimali pupovi za opskrbljivanje rasadničara.

Iz analiziranih primjera Španjolske i Italije utvrđeno je kako Španjolska ima samo jedan centar za provođenje certifikacijskog programa agruma, koji provodi IVIA, dok Italija ima nekoliko centara podijeljenih po regijama, u kojima se provodi certifikacijski program za više voćnih vrsta zajedno, uključujući agrume. U ovom radu preuzeti su koraci u uspostavljanju nasada više kategorije prema četiri osnovna koraka, a to su: uspostava predosnovnog i osnovnog matičnog nasada, čuvanje biljnog materijala u mrežarniku, podizanje gustog sklopa „Increase block“ i opskrba rasadničara bezvirusnim plemkama.

Izgradnja mrežarnika, prilagođenim karakterističnim uvjetima okoline, je temeljni uvjet za početak rada na uspostavi nužno potrebnog procesa podizanja matičnih nasada agruma u Republici Hrvatskoj.

Uspjeh cijelokupnog procesa i uspostava certifikacijske sheme ovisit će o stupnju implementacije zdravog sadnog materijala u matičnim nasadima rasadničara u dolini Neretve, odnosno, stupnju uspostave nezaraženog sadnog materijala u proizvodnim nasadima. Prema uspješnim iskustvima Španjolske i 
Italije, jasno je da se radi o opsežnoj reformi sustava proizvodnje agruma koju je potrebno cjelovito i sustavno provoditi.

\section{LITERATURA}

AUBERT B., VULLIN G. (1998.): Citrus nurseries and planting techniques, CIRAD, Montpellier

BAKARIĆ, P. (1974.): Uzgoj limuna u zatvorenim prostorijama, Nolit, Beograd BAKARIĆ, P. (1994.): Uzgoj limuna u domu i dvorištu, Grafoplast, Zagreb BAKARIĆ, P. (1998.): Naranča, Zadružni savez Dalmacije Zadrugar, Split BAKARIĆ, P. (1983.). Uzgoj mandarine Unšiju, Stanica za južne kulture, Dubrovnik

BARABA V., GOLUŽA V., KAPOVIĆ J., DUGANĐIĆ G. (1987.): Štete od niskih temperatura u proizvodnim nasadima mandarina PIK-a "Neretva" Opuzen, Agronomski glasnik br. 6, p. 87-94.

BENIĆ - PENAVA, M. (2017): Rasadnik Čibača (1911.-1932.), Anali Dubrovnik vol. 55/2, p. 521-539..

CATALANO L. (2007): Improvement of fruit industry by the certification of plant propagating material, Consorzio Vivaistico Pugliese -COVIP, p.1113.

CRNOMARKOVIĆ D., KIRIDŽIJA M. (2013.): Neretvanska mandarinaspecifikacija proizvoda, Neretvanska udruga voćara „Mandarina - Opuzen“, p.1-12, Opuzen

ČMELIK Z., HUSNJAK S., STRIKIĆ F., RADUNIĆ M. (2010): Regionalizacija voćarske proizvodnje u Republici Hrvatskoj, Pomologia Croatica vol. 1-2, p. 13-36.

DJELOVAH K., VALENTINI F., D'ONGHIA A. M. (2009.): Historical review of Citrus tristeza virus in Italy, CIHEAM: Options Mediterraneennes vol. 65 , p. 59-62, Bari, Italy

FESTIĆ H. (1979.): Viroze voćaka i vinove loze, Sarajevo: Nigro "GLAS" štamparija, Banja Luka.

GATIN, Ž. (1978.): Razvoj proizvodnje citrusa u delti Neretve, Poljoprivreda i šumarstvo 3-4, p. 131-157. 
GUGIĆ J., CUKROV L. (2011.): Pregled stanja i perspektiva razvoja hrvatskog agrumarstva, Pomologia Croatica 3-4, p. 115-133.

IVIĆ D., KAJIĆ V., MILANOVIĆ J., FAZINIĆ T., BUDNIŠĆAK Ž. (2012.): PPV i CTV - karantenski virusi u matičnim nasadima Hrvatske. Zbornik sažetaka 56. seminara biljne zaštite, Glasilo biljne zaštite 12, p. 56-57, Opatija

IVIĆ, D., FAZINIĆ T. (2011.): Certifikacijske sheme za proizvodnju sadnog materijala značajnih voćnih vrsta u Hrvatskoj, Pomologia Croatica 1-2, p. 31-36.

KALEB, M. (2014): Razvoj uzgoja mandarina i ostalih agruma u dolini Neretve, Agronomski glasnik br. 4-5, p. 219- 238.

MARIĆ M., DRUŽIĆ J., DESNICA S., BARNJAK-VUKAS M. (2015): Sedamdeset godina stanice za južne kulture u Dubrovniku, Zbornik Sveučilišta u Dubrovniku br. 2, p. 99- 124.

MILJKOVIĆ I., ET AL. (1983): Aktualni problemi i smjernice za razvoj voćarstva u mediteranskom području Jugoslavije. II. Simpozij o voćarstvu Mediterana u Zadru. 1983. (glavni referat). Jugoslavensko voćarstvo, br. 6364, p. 5-29.

MILJKOVIĆ, I. (1991): Suvremeno voćarstvo, Zagreb: Nakladni zavod Znanje.

MINISTARSTVO POLJOPRIVREDE (2016): Plan podizanja kvalitete matičnih nasada agruma u Republici Hrvatskoj, Zagreb.

MINISTARSTVO POLJOPRIVREDE (2017): Pravilnik o stavljanju na tržište reprodukcijskog sadnog materijala i sadnica namijenjenih za proizvodnju voća, Narodne novine 9/17, Zagreb

MONTALT R. (2009): Partenocarpia en citricos. Estudio preliminar para la caracterizacion del banco de germoplasma de citricos del IVIA, Master edition, Universidad politecnica de Valencia, Valencija

NAVARRO L., (1976): The Citrus Improvement Program in Spain, Proc. 7th Conference IOCV, p. 198-203. IOCV, Riverside, CA

NAVARRO L., BALLESTER J.F., JUAREZ J., PINA J.A., ARREGUI J.M., BONO R. (1981): Citrus shoot-tip grafting in vitro (STG) and its applications: A review, Proc. Int. Soco Citriculture vol. 1, p. 70-73. 
NAVARRO L., JUAREZ J., DURAN-VILA N., CAMBRA M. (2002): The citrus varety improvement program in Spain in the period 1975-2001, Proc. 15th Conference IOCV, p. 306-316, Riverside, CA

NIKOLAC N., BATINOVIĆ I. (1987): Osjetljivost mandarina na raznim podlogama prema niskim temperaturama, Agronomski glasnik br. 6, p. 95102.

OEEP/EPPO (1998): Certification schemes. Patogen tested citrus trees and rootstocks EPPO standards PM 4/12 (1), European and Mediterranean Plant Protection Organization.

ROISTACHER C.N., NAVARRO L., MURASHIGE T. (1976): Recovery of citrus selections free of several viruses Exocortis Viroid and Spiroplasma citri by shoot-tip grafting in vitro, Proc. 7th Conference IOCV, p.186-193, Riverside, CA

ROŠIN J,. HANČEVIĆ K., RADUNIĆ M. (2009): Predosnovni matični nasad agruma, Pomologia Croatica, vol. 3-4, p. 129-139.

SAVINO V., D'ONGHIA A. M. (1998): Certification of Citrus in Italy, CIHEAM: Options Mediterraneennes vol. 21, p. 37-43, Bari, Italy

TABAIN F. (1975): Uzgoj agruma, Znanje, Zagreb

VAPNEK, J. (2009.): Legislatively establishing a health certification programme for citrus, FAO Leal papers online 81, p. 1-18, Rim, Italy

VIVES M.C. (2016.): The Citrus Variety Improvement Program in Spain, Instituto Valenciano de Investigaciones Agrarias -IVIA (PowerPoint prezentacija osobno preuzeta tijekom susreta s IVIA-om u Španjolskoj 20.2.2017)

\section{Web stranice:}

Bettini O. (2016): Global Agricultural Information Network www.gain.fas.usda.gov [23. Svibanj, 2017].

Catalano L. (2008): Organization of the Italian certification scheme for Citrus, www.docplayer.net/Organization-of-the-italian-certification-scheme-forcitrus [23. Svibanj, 2017].

Centro di riserca (2016): www.crfsa.it [1. Lipanj, 2017] 
DHMZ (2016): Mjesečne vrijednosti za Dubrovnik u razdoblju 1961-2015, http://klima.hr/klima.php?id=k1\&param=srednjak\&Grad=dubrovnik $\quad[28$. Svibanj, 2017].

Institut Valencià d'Investigacions Agràries (2016): www.ivia.gva.es/ca/origeny-funciones [17. Travanj, 2017].

Ljubičić S. (2015): Neretvom bjesni rat za zemlju vrijednu 300 milijuna eura, Slobodna Dalmacija, www.slobodnadalmacija.hr [6. Lipanj, 2017]

Musulin N. (2015): 30 tisuća tona mandarina u milosti tržišta www.agroklub.hr [31. Svibanj, 2017]

Sočković, K. (2017): Značajan rast izvoza hrane, https://privredni.hr/vijesti/24analize/2142-znacajan-rast-izvoza-hrane [19. Svibanj, 2017].

Soldo S. (2004): Metković postaje Salt Lake City, Slobodna Dalmacija, www.slobodnadalmacija.hr [6. Lipanj, 2017]

Valverde C. (2016): Global Agricultural Information Network www.gain.fas.usda.gov [27. Svibanj, 2017].

\section{Adrese autora - Author's adress:}

Doc. dr. sc Mara Marić,

e - mail: mara.maric@unidu.hr

Mag. ing. agr Ivana Paladin

e - mail: ivana.paladin@unidu.hr

Sveučilište u Dubrovniku,

Zavod za mediteranske kulture,

Marka Marojice 4, 20000 Dubrovnik 
